\title{
Prosedur dan Jenis Permintaan Visum et Repertum di Rumah Sakit: Literature Review
}

\author{
Dies Puji Ramadhani, Ida Sugiarti \\ Program Studi D3 Rekam Medis dan Informasi Kesehatan, Poltekkes Kemenkes Tasikmalaya, Indonesia \\ Jl.. Cilolohan No. 35, Kel.Kahuripan, Kec. Tawang, Kota Tasikmalaya, Jawa Barat 46115 \\ Korepondensi E-mail: ida.sugiarti@dosen.poltekkestasikmalaya.ac.id
}

Submitted: 7 September 2021, Revised: 8 Desember 2021, Accepted: 14 Desember 2021

\begin{abstract}
$V$ isum et repertum $(\mathrm{VeR})$ is a medical certificate used for judicial needs in the form of a written report made by a doctor containing the results of the examination. $V e \mathrm{R}$ is one of the five legal pieces of evidence in court. Making a VeR that is not following hospital procedures can lead to the submission of evidence in court proceedings. This study aims to determine the standard procedure for implementing medical information for $\mathrm{Ve} \mathrm{R}$ and the types of cases for which a $\mathrm{VeR}$ is requested. This type of research is a literature review using Google Scholar and Garuda databases with a boolean system strategy. The flow of the implementation of patient medical information for $V e \mathrm{R}$ begins with the police submitting a letter of request for $V e \mathrm{R}$ to the hospital administration by bringing the requirements of an official request letter from the director of the hospital. The visa request letter and the report are placed in the Medical Record Installation for further processing by the Medical Record. The types of cases requested for $V e \mathrm{R}$ are divided into two, namely for living victims and dead victims. Living victims are divided into injuries, sexual crimes, and psychiatric.
\end{abstract}

Keywords: literature review, visum et repertum ( $V e R)$, fixed procedure, type of request.

\begin{abstract}
Abstrak
Visum et repertum (VeR) merupakan surat keterangan medis yang sifatnya dipergunakan untuk kebutuhan peradilan berupa laporan tertulis yang dibuat oleh dokter yang memuat hasil pemeriksaan. Visum et Repertum merupakan salah satu dari lima alat bukti yang sah di pengadilan. Pembuatan visum et repertum yang tidak sesuai dengan prosedur tetap rumah sakit dapat menghambat penyampaian bukti dalam proses pengadilan. Penelitian bertujuan untuk mengetahui prosedur tetap pelaksanaan pelepasan informasi medis untuk keperluan visum et repertum serta jenis permintaan visum et repertum. Jenis penelitian adalah literature review menggunakan database Google Scholar dan Garuda dengan strategi boolean system. Alur pelaksanaan pelepasan informasi medis pasien untuk keperluan visum et repertum dimulai dengan pihak kepolisian menyerahkan surat permintaan visum et repertum ke bagian tata usaha Rumah Sakit dengan membawa persyaratan surat permohonan resmi dari kepolisian kepada direktur Rumah Sakit. Surat permintaan visum et repertum tersebut didisposisikan ke Instalasi Rekam Medis untuk selanjutnya diproses. Jenis kasus yang dimintakan visum et repertum dibagi menjadi dua, yaitu untuk korban hidup dan korban mati. Korban hidup terbagi menjadi perlukaan, kejahatan seksual, dan psikiatrik.
\end{abstract}

Kata Kunci: literature review, visum et repertum, prosedur tetap, jenis permintaan

\section{Pendahuluan}

Perkembangan teknologi memberikan pengaruh terhadap kehidupan manusia baik itu pengaruh positif maupun negatif. Pengaruh negatif dari kemajuan teknologi diantaranya kemudahan akses terhadap tayangan yang mengandung kekerasan. Salah satu perilaku kekerasan yang sering muncul adalah kekerasan seksual anak usia dini (1). Informasi yang didapatkan dari Komisi Perlindungan Anak Indonesia menyatakan bahwa kasus tersebut banyak terjadi di Jakarta, Medan, dan Jawa Barat dengan total 2.792 kasus (1). Mirisnya mayoritas pelaku dari tindak kekerasan seksual ini adalah orang terdekat korban. Semua bentuk kekerasan baik fisik, kekerasan seksual, kekerasan moral, kekerasan psikiatri, dan kekerasan lainnya, besar kemungkinan menimbulkan kerugian bagi salah satu pihak. Pihak yang dirugikan seringkali menuntut sebuah peradilan kepada pihak kepolisian.

Pihak kepolisian tidak dapat bekerja sendiri dalam mengungkap kasus kekerasan, mereka memerlukan surat keterangan medis sebagai bekal di pengadilan. Hal ini senada dengan penelitian (2), yang menyatakan bahwa petugas keamanan tidak dapat menangani permasalahan sendiri, mereka membutuhkan keterangan ahli untuk mendapatkan fakta ilmiah terhadap kondisi korban sebenarnya (2). 
Salah satu pelayanan kesehatan yang dituju ketika membutuhkan surat keterangan medis untuk kebutuhan pengadilan adalah rumah sakit yang melayani pembuatan surat keterangan visum et repertum.

Tahapan pembuatan visum et repertum diawali dengan penerimaan korban dari petugas keamanan beserta surat permintaan visum et repertum, pemeriksaan fisik korban, penulisan dan penandatanganan visum et repertum, penyerahan benda bukti dan lembar visum et repertum (3). Pembuatan lembar keterangan medis yang tidak memenuhi prosedur tetap dapat berdampak pada tersebarnya informasi kesehatan pasien yang seharusnya dirahasiakan oleh pihak fasilitas pelayanan kesehatan. Hal ini tentu berbahaya karena dikhawatirkan akan menjadi aib dan kemudian tersebar ke masyarakat umum. Dampak lain dari pembuatan visum et repertum yang tidak sesuai dengan prosedur tetap adalah lambatnya proses hukum.

Penelitian lain (4) mengungkapkan bahwa keterlambatan penyerahan surat keterangan medis pasien dapat mempengaruhi kualitas layanan terhadap pasien, dan proses pengadilan menjadi terbengkalai (4). Ditinjau dari hasil penelitian terdahulu, maka dapat dikatakan pelaksanaan pembuatan visum et repertum yang sesuai dengan prosedur tetap menjadi penting untuk dilakukan dikarenakan tingginya angka kekerasan yang memerlukan surat keterangan medis untuk keperluan pengadilan.

Penelitian ini menggunakan pendekatan literature review dengan metode PICO. Dimana P (population): prosedur/alur pembuatan dan jenis kasus yang dimintakan visum et repertum periode 2016 2020, I (Intervention): faktor, dan O (outcome): gambaran prosedur/pembuatan dan jenis permintaan visum et repertum periode 2016 - 2020. Tujuan penelitian untuk mengetahui prosedur/pembuatan visum et repertum dan jenis kasus yang dimintakan visum et repertum periode $2016-2020$.

\section{Metode Penelitian}

Penelitian ini menggunakan literature review dengan kata kunci visum et repertum, Rumah Sakit, dan kualitatif. Database pada penelitian ini adalah Google Scholar dan Garuda. Strategi pencarian menggunakan boolean system. Pencarian data literature dengan menggunakan database Google Scholar dan Garuda sesuai dengan kata kunci dan strategi pencarian yang dilakukan didapatkan hasil sebanyak 547 jurnal yang kemudian dilakukan seleksi inklusi eksklusi sehingga didapatkan 15 jurnal yang sesuai dengan tema penelitian yang dibutuhkan. Seleksi inklusi dalam penelitian ini terdiri dari 4 (empat) aspek sebagai berikut:

1. Penelitian yang dipublikasikan tahun 2016 - 2020;

2. Pelepasan informasi medis pasien untuk keperluan visum et repertum;

3. Jenis permintaan visum et repertum; dan

4. Prosedur pembuatan visum et repertum.

Seleksi eksklusi yang digunakan dalam penelitian ini adalah sebagai berikut:

1. Jurnal sesuai namun tidak dapat diakses;

2. Pelepasan informasi medis pasien untuk keperluan asuransi dan pendidikan;

3. Jurnal sudah sesuai namun tidak full text, dan

4. Kedudukan visum et repertum dalam mengungkap kasus pidana..

\section{Hasil dan Pembahasan}

\section{Prosedur/Alur Pembuatan Visum et Repertum}

Pembuatan surat keterangan medis dilakukan dengan kunjungan pasien terlebih dahulu ke rumah sakit dengan membawa surat permintaan dari pihak kepolisian. Surat tersebut disampaikan ke bagian rekam medis untuk selanjutnya dilakukan pemeriksaan oleh dokter sebagai bahan pengisian visum et repertum. Informasi dalam lembar tersebut diketik ulang oleh petugas rekam medis dan ditandatangani oleh dokter pemeriksa. Petugas kepolisian kemudian dipanggil kembali untuk mengambil visum et repertum dengan menandatangani buku ekspedisi pengambilan visum.

Adapun, kegiatan yang berhubungan dengan petugas rekam medis adalah proses pelaksanaan pengetikan visum et repertum. Proses pengetikan visum et repertum yang jelas dan tepat penting untuk diperhatikan karena berpengaruh terhadap kegunaan lembar visum et repertum di pengadilan. Komponen pembukaan kualitasnya masih menengah (60\%), bahkan berkualitas buruk pada komponen hasil pemeriksaan (45\%) dan simpulan (20\%) serta termasuk dalam kategori buruk (5). Penyebab dari ketidaksesuaian alur pembuatan visum et repertum adalah karena ketidaktahuan petugas rekam medis terhadap prosedur tetap di rumah sakit. Ketidaktahuan petugas mengenai prosedur tetap disebabkan 
karena prosedur tersebut belum disosialisasikan. Tetapi masih ada rumah sakit yang sudah melaksanakan pembuatan visum et repertum sesuai prosedur tetap diantaranya adalah Rumah Sakit Umum Muhammadiyah Kabupaten Ponorogo (6).

Berdasarkan 6 (enam) jurnal yang menjelaskan mengenai alur pembuatan surat keterangan medis, dapat diketahui bahwa tahapan terkait pembuatan surat keterangan medis tiap Rumah Sakit berbedabeda. Alur pembuatan surat keterangan medis di RSUD Kota Salatiga dilakukan dengan penyerahan surat permintaan pembuatan visum et repertum dari petugas kepolisian ke rumah sakit (11). Surat tersebut kemudian didisposisikan ke bagian Rekam Medis untuk diproses ke tahap selanjutnya.

Rumah sakit lain memiliki alur penyusunan surat keterangan medis yang berbeda, yakni dimulai dengan pasien datang ke Instalasi Gawat Darurat dengan membawa surat permintaan dari kepolisian (4). Surat tersebut akan didisposisikan ke bagian Rekam Medis yang selanjutnya pasien diperiksa oleh dokter sebagai bahan pembuatan surat keterangan medis. Informasi tersebut diketik ulang oleh petugas rekam medis dan ditandatangani oleh dokter penanggung jawab pasien. Lembar visum et repertum yang sudah selesai dibuat disimpan dulu di ruang filing untuk selanjutnya diberikan kepada polisi dengan menandatangani buku ekspedisi terlebih dahulu.

Secara garis besar, prosedur tetap pembuatan surat keterangan medis belum sesuai dengan teori (3). Dalam teori tersebut pembuatan visum et repertum dilakukan sebagai berikut:

a. Penyidik mengirim korban ke fasilitas pelayanan kesehatan yang melayani pembuatan visum et repertum;

b. Surat permintaan visum et repertum diterima oleh rumah sakit;

c. Korban diperiksa oleh dokter;

d. Visum et repertum diketik ulang oleh petugas rekam medis;

e. $\quad$ Dokter menandatangani visum et repertum yang telah selesai diketik ulang;

f. Barang bukti yang telah diperiksa diserahkan kembali kepada pihak yang berwenang; dan

g. Pelepasan visum et repertum.

Terdapat ketidaksesuaian dengan teori, yaitu prosesnya belum menyatakan dengan detail terkait dengan langkah ketiga sampai terakhir, yakni dari mulai korban diperiksa oleh dokter sampai dengan pelepasan visum et repertum. Kemudian dalam prosedur tetap tersebut tidak dijelaskan secara rinci terkait jabatan kepolisian yang mengajukan surat permintaan visum et repertum. Padahal berdasarkan KUHAP Pasal 6 Ayat 1 tentang Pelaksanaan Peraturan Pemerintah Nomor 27 Tahun 1983 tentang tentang Pelaksanaan Kitab Undang-Undang Hukum Acara Pidana Pasal 2 ayat 1 adalah Pejabat Polisi Negara Kesatuan Republik Indonesia yang diberi wewenang khusus dengan pangkat serendah - rendahnya Pembantu Letnan Dua dan penyidik pembantu berpangkat serendah - rendahnya Sersan Dua. Jika penyidik tersebut adalah Pegawai Negeri Sipil (PNS), maka kepangkatannya adalah serendah - rendahnya golongan II/b untuk penyidik dan II/a untuk penyidik pembantu.

Aspek lain dalam alur pembuatan visum et repertum yang perlu mendapat perhatian lebih adalah tahap keempat dalam alur pembuatan surat keterangan medis, yaitu pada tahap pengetikan. Tahap ini penting diperhatikan karena berhubungan dengan petugas administrasi dalam hal ini profesi rekam medis. Pelaksanaannya di beberapa fasilitas pelayanan kesehatan kualitas lembar visum et repertum belum baik. Contohnya di Rumah Sakit Umum Haji Medan pengetikan visum et repertum pada bagian pendahuluan kualitasnya 60\% (kategori sedang) karena aspek pendahuluan tidak dicantumkan dengan lengkap pada bagian tempat pemeriksaan dan nama dokter tidak ditulis(12). Dari sampel yang diteliti, lembar visum et repertum pada bagian pendahuluan hanya mencantumkan waktu pemeriksaan, data korban serta data penyidik. Kemudian untuk bagian hasil pemeriksaan masuk ke dalam kualitas sedang yaitu 58,33\%. Pada bagian ini semua lembar visum et repertum sudah menyertakan hasil tanda vital korban namun belum mencantumkan karakteristik luka dan riwayat pengobatan. Penulisan hasil pemeriksaan yang seperti ini dapat menyulitkan pembuatan kesimpulan. Terakhir untuk bagian kesimpulan, kualitasnya justru yang paling rendah yaitu 50\% dan termasuk kategori sedang. Bagian kesimpulan ini seharusnya mencantumkan jenis dan kualifikasi luka. Namun informasi tersebut tidak dicantumkan dengan lengkap terutama kualifikasi luka, padahal poin ini yang sebenarnya dibutuhkan di pengadilan.

Keadaan tersebut tidak sesuai dengan teori (13) yang mengungkapkan komponen yang harus ada dalam surat keterangan medis sebagai berikut :

a. Bagian pembukaan dengan menuliskan "Pro Justitia";

b. Bagian pendahuluan yang terdiri dari identitas penyidik, dokter pemeriksa, dan pasien; 
c. Bagian hasil pemeriksaan yang terdiri dari temuan medis, tindakan, dan kondisi terakhir pasien;

d. Bagian kesimpulan yang menjelaskan hasil pemeriksaan dengan menyebutkan luka serta kualifikasi luka; dan

e. Bagian penutup yakni kalimat "demikian visum et repertum ini dibuat dengan sebenar - benarnya, berdasarkan keilmuan mengingat sumpah dan sesuai dengan KUHAP”

Berdasarkan hasil penelitian dari 6 (enam) jurnal yang diteliti dan teori yang disampaikan oleh Afandi (2017) dan Susanto \& Sugiharto (2017) serta dikaitkan dengan KUHAP Pasal 6 Ayat 1, maka dapat ditarik kesimpulan bahwa prosedur/alur pembuatan visum et repertum belum terlaksana dengan baik. Hal ini dapat memicu penyalahgunaan penggunaan informasi medis terhadap pihak yang tidak bertanggung - jawab karena tidak diperhatikannya jabatan kepolisian yang mengajukan surat permohonan visum et repertum. Selain itu, pemberian informasi pada proses pengetikan surat keterangan visum et repertum yang tidak berkualitas baik (100\%) karena menyajikan informasi yang jelas dan tepat menyebabkan lembar visum et repertum menjadi kurang berguna di pengadilan.

\section{Jenis Permintaan Visum et Repertum}

a. Korban Hidup

1) Perlukaan

Kasus perlukaan merupakan salah satu jenis kasus visum et repertum pada korban hidup. Salah satu dari jenis kasus yang dimintakan surat keterangan medis perlukaan adalah pada kasus kecelakaan. Rumah Sakit Umum Pusat Dokter Mohammad Hoesin Palembang tercatat menangani banyak korban yang meminta surat keterangan medis pada korban lakilaki $(78,35 \%)$ disertai dengan luka robek (40\%) (7). Permintaan visum et repertum kasus penganiayaan di Rumah Sakit Umum Pusat Dokter Soeradji Tirtonegoro Klaten termasuk tinggi dengan jumlah korban sebanyak 109 orang (8).

2) Kejahatan Seksual

Jenis permintaan yang kedua adalah kasus kejahatan seksual yang banyak diajukan di Rumah Sakit Cut Meutia. Hal ini menunjukkan masih tingginya angka pelecehan seksual di Indonesia hingga mencapai jumlah 24 orang pada rentang usia $5-14$ tahun (9). Adapun pelaku kejahatan seksual terbanyak adalah pacar korban itu sendiri dengan jumlah mencapai 45 kasus yang tercatat di Rumah Sakit Bhayangkara Manado, dengan jumlah korban terbanyak adalah berjenis kelamin perempuan (112 orang) (10). Akibat dari kasus kejahatan seksual ini adalah hilangnya kehormatan perempuan karena menimbulkan robeknya selaput dara berdasarkan pemeriksaan pada 80 orang korban.

3) Psikiatrik

Korban terbanyak pada kasus ini adalah mereka yang berusia produktif ( 22 - 40 tahun), dengan jumlah 81 kasus dan melingkupi kasus perlukaan, kejahatan seksual, dan psikiatrik di Rumah Sakit Umum Pusat Dokter Soeradji Tirtonegoro Klaten (8).

RSUP Dokter Soeradji Tirtonegoro Klaten pertama kali membuka pelayanan forensik pada tahun 2014 dan sudah menangani banyak kasus. Pada korban hidup, kasus yang ditangani adalah sebagai berikut:

1) Perlukaan;

2) Kejahatan seksual; dan

3) Psikiatrik.

Ketiga kasus tersebut sesuai dengan pernyataan Afandi (2017) yang menyatakan bahwa jenis kasus korban hidup terbagi menjadi 3 (tiga) jenis yakni visum et repertum untuk korban perlukaan, kejahatan seksual, dan psikiatrik.

RSUP Dokter Soeradji Tirtonegoro Klaten melayani pembuatan surat keterangan medis korban hidup, di Rumah Sakit lain juga menerima pelayanan pembuatan surat keterangan medis pada korban hidup. Rumah Sakit Bhayangkara Manado telah melakukan pelayanan pembuatan surat keterangan medis kasus kejahatan seksual sebanyak 110 kasus pada periode Juli 2015 Juni 2016 (10). Rumah Sakit M. Djamil Padang juga melayani pembuatan visum et repertum pada korban perlukaan sebanyak 10 kasus pada periode Agustus - November 2017(14). 
Berdasarkan hasil penelitian dan teori yang mendukung, peneliti berasumsi bahwa semakin banyaknya instansi yang menerima pelayanan pembuatan visum et repertum, maka kemungkinan korban mendapatkan keadilan akan semakin tinggi. Hal ini dikarenakan lembar keterangan medis dapat menjadi bukti akurat bahwa seseorang tersebut benar - benar mengalami kerugian, dan pelaku harus mendapatkan hukuman akibat perbuatannya.

\section{b. Korban Mati}

Permintaan surat keterangan medis untuk korban mati juga dapat dilayani di fasilitas pelayanan kesehatan. Hal ini berguna sebagai salah satu upaya dalam mengungkap delik pembunuhan. Namun, upaya ini justru terkendala karena adanya opini di masyarakat yang beranggapan bahwa praktik kedokteran forensik tidak menghormati mayit ditinjau dari pemahaman mereka dari sudut pandang agama. Padahal, lembar visum et repertum akan berguna di pangadilan dalam mengungkap sebuah perkara tindak pidana. Apalagi jika mengingat jumlah kasus mati yang masih terhitung banyak. Jumlah kasus mati di Rumah Sakit Umum Pusat Dokter Soeradji Tirtonegoro Klaten dalam periode 2014 - 2016 tercatat sudah menangani 23 kasus mati dengan perincian 6 korban wanita dan 17 korban pria. Mereka 100\% korban kecelakaan lalu lintas dengan penabrak yang tidak diketahui identitasnya(8).

RSUP Dokter Soeradji Tirtonegoro Klaten telah menangani 23 permintaan pembuatan visum et repertum untuk korban mati. Pernyataan ini sesuai dengan yang diungkapkan oleh Afandi (2017) bahwa surat keterangan medis korban mati diperuntukkan bagi jenazah. Adapun jenazah yang dimaksud diperjelas dengan jenazah korban yang meninggal akibat kecelakaan lalu lintas, kriminal, dan kematian lain.

Korban meninggal karena kematian lain salah satunya adalah korban pembunuhan. Kasus pembunuhan masih tergolong banyak di wilayah hukum Polrestabes Makassar (15). Pengungkapan delik pembunuhan memerlukan bukti yang sah dalam bentuk surat keterangan medis yang ditulis oleh seseorang yang memiliki keahlian di bidang kesehatan. Hal ini sesuai dengan Pasal 120 Ayat 1 KUHAP yang menyatakan diperlukannya bantuan seorang ahli untuk mendapatkan kebenaran materil selengkap - lengkapnya bagi para penegak hukum.

Berdasarkan hasil penelitian, semakin terbukanya pelayanan pembuatan surat keterangan medis pada korban mati akan membuat semakin banyaknya pengungkapan kasus terhadap kematian seseorang yang tidak wajar. Hal ini berguna demi tegaknya keadilan, supaya pelaku mendapatkan hukuman yang setimpal dengan perbuatannya karena telah menghilangkan nyawa seseorang.

\section{Kesimpulan}

Prosedur/alur pembuatan visum et repertum diawali dengan pasien mendatangi pihak kepolisian, kemudian polisi menyerahkan surat permintaan visum et repertum dan didisposisi untuk diserahkan ke rumah sakit. Pihak rumah sakit mencatat di buku ekspedisi penerimaan, adapun yang sudah ada disposisi dicari berkasnya. Pasien diperiksa, dan formulir visum et repertum diisi oleh dokter. Visum et repertum diketik ulang oleh PMIK dan diserahkan kepada dokter untuk ditanda-tangani. Lembar tersebut kemudian disimpan di ruang penyimpanan rekam medis dan dapat diambil ke ruangan tersebut apabila dibutuhkan. Prosedur tetap yang telah disahkan oleh rumah sakit belum sepenuhnya sesuai dengan teori terutama pada pemeriksaan korban secara medis, pengetikan surat keterangan visum et repertum, penyerahan benda/bukti yang telah diperiksa, dan prosedur penyerahan surat keterangan visum et repertum. Isi dari visum et repertum belum sepenuhnya baik karena masih ada beberapa ketidaklengkapan pengisian. Jenis permintaan visum et repertum di rumah sakit periode 2016 - 2020 dibagi menjadi dua jenis yaitu untuk korban hidup, dan korban mati. Korban mati terbagi menjadi 3 (tiga) jenis yaitu perlukaan, kejahatan seksual, dan psikiatrik. Sementara pada korban mati adalah pembuatan visum et repertum terhadap jenazah. Pada pelaksanaannya sudah banyak rumah sakit yang menerima pelayanan kedokteran forensik, hal ini tentu akan memudahkan pihak pengadilan dalam mendapatkan alat bukti sebagai bahan untuk menyelesaikan suatu kasus tindak pidana. Ada hambatan lain dalam pembuatan visum et repertum korban mati, yakni adanya opini di masyarakat yang menyatakan bahwa praktik kedokteran forensik tidak sesuai dengan ajaran agama karena dianggap tidak menghormati mayat. 


\section{Ucapan Terimakasih}

Direktur Politeknik Kesehatan Kementerian Kesehatan Tasikmalaya dan semua pihak yang telah membantu menyelesaikan penelitian ini.

\section{Daftar Pustaka}

1. Ningsih ESB, Hennyati S. Kekerasan Seksual Pada Anak Di Kabupaten Karawang. Midwife J [Internet]. 2018;4(02):56-65. Available from: http://jurnal.ibijabar.org/kekerasan-seksual-pada-anak-dikabupaten-karawang/

2. Lubis MSF. Peranan Visum et Repertum pada Tahap Penyidikan yang Dilakukan Polres Asaban pada Kasus Tindak Pidana Pemerkosaan Sesuai dengan Kitab Undang-Undang Hukum Acara Pidana. J Pionir LPPM Univ Asahan Vol 2 N03 Juli-Desember 2017 [Internet]. 2017; Available from: http://jurnal.una.ac.id/index.php/pionir/article/view/185/161

3. Afandi D. Visum et Repertum Tata Laksana dan Teknik Pembuatan Edisi Kedua [Internet]. Kedua. Riau: Fakultas Kedokteran Universitas Riau; 2017. 1-80 p. Available from: http://fk.unri.ac.id

4. Lapenia P, Masturoh I. Pemanfaatan Rekam Medis Sebagai Alat Bukti Dalam Persidangan. J Manaj Inf Kesehat Indones [Internet]. 2019;129-36. Available from: https://jmiki.aptirmik.or.id/index.php/jmiki/article/view/129

5. Lubis A, Petrus A, Parinduri AG. The Quality of Visum Et Repertum on the Injuries of Living Victims in Deli Serdang General Hospital in 2017-2018. 2020;7(1):83-8. Available from: http: // www.ijrsm.com

6. Murnisari et al. Tinjauan Pengelolaan Visum Et Repertum Di Rumah Sakit Umum Mubammadiyah Kabupaten Ponorogo. Glob Heal Sci Vol 3 No 3, Sept 2018 ISSN 2503-5088 2622-1055. 2018;3(4):339_ 45.

7. Singh SKA, Nasution IS, Hayati L. Angka Kejadian Korban Kecelakaan Lalu Lintas Berdasarkan Hasil Pemeriksaan Luar Visum Et Repertum di RSUP Dr. Mohammad Hoesin Palembang Tabun 2011-2013. Maj Kedokt Sriwij. 2015;47(2):105-9.

8. Wiraagni IA, Widihartono E. Karakteristik kasus pada Visum et Repertum di RSUP dr. Soeradji Tirtonegoro Klaten 2014-2016. Pharmaciana. 2016;6(2):163-70.

9. Albin I, Zubir. Karakteristik Kasus Kekerasan Seksual Pada Perempuan Di Blud Rumah Sakit Cut Meutia Berdasarkan Visum Et Repertum Periode Tahun 2018. AVERROUS J Kedokt dan Kesehat Malikussaleh. 2020;6(1):63.

10. Ong F, Mallo J, Mallo NTS. Gambaran Visum et Repertum kasus kekerasan terbadap anak di RS. Bhayangkara Manado periode Juli 2015 - Juni 2016. J Kedokt Komunitas Dan Trop. 2016;4(4):159-62.

11. Warijan W, Widodo W, Nur'afifah MM. Tinjauan Pelaksanaan Pelepasan Informasi Medis. J Rekam Medis dan Inf Kesehat. 2019;2(1):20.

12. Petrus A, Lubis A. Kualitas Visum Et Repertum Perlukaan Korban Hidup Di Rsu.Haji Medan Periode 1 Maret 2018 S.D 31 Maret 2019. J Kedokt Methodist [Internet]. 2019;12:6-13. Available from: http://ojs.lppmmethodistmedan.net

13. Susanto E, Sugiharto. Bahan Ajar RMIK Manajemen Informasi Kesehatan IV; Etika Profesi \& Hukum Kesehatan [Internet]. Jakarta: BPPSDM Kementerian Kesehatan RI; 2017. 1-178 p. Available from: ilep-poltekes.kemkes.go.id/\#20-rekam-medis-dan-informasi-kesehatan

14. Manela C, Hidayat T. Korelasi Kadar Alkohol dengan Derajat Luka Dalam Hal Pembuatan Visum Et Repertum pada Pasien Kecelakaan Lalu Lintas Rumah Sakit M. Djamil Padang. J Kesehat Andalas. 2018;7(3):370.

15. Lisdayanty. Phinisi Integration Review Kedudukan Visum Et Repertum Dalam Pengungkapan Delik. 2019;2(2). Available from: http://ojs.unm.ac.id/pir 